\title{
Behavioural Responses of Tilapia mossambica to Water Polluted with Fly Ash from Coal: a Laboratory Study
}

\author{
Shikha Shrivastava (Corresponding author) \\ Department of zoology, Government Vytpg Autonomous College \\ Durg, C.G, India \\ E-mail: shikhapk@yahoo.com, gainbrain@yahoo.co.in \\ Usha Thakur \\ Digvijaya College, Rajnandgaon, C.G. India \\ Lekhika Shrivastava \\ Department of zoology, Government Vytpg Autonomous College \\ Durg, C.G. India
}

\begin{abstract}
Fly ash contains many elements, including heavy metals, ions and oxides, depending on the constituents of the coal being fired for power generation, where fly ash is a byproduct. These compounds affect the water quality and in turn the fish and their behaviour. Changes in water quality parameters may also be detrimental to the aquatic flora and hence indirectly influence the local fish population. Deviation from normal behavior is the first sign for any animal that it is coping with some internal physiological stress. This study investigates the effect of fly ash on the behavioural pattern of Tilapia mossambica. Observations were done on the movements of their operculum and pectoral fins. Additionally, their feeding and swimming habits were studied as well as their sensory responses (e.g. acoustic, rheological aggressiveness etc.). Fish in water containing fly ash were compared to fish in water without fly ash under laboratory conditions.
\end{abstract}

Keywords: Fly ash, Tilapia, Pollution, Behaviour, Stress

\section{Introduction}

Fly ash, a byproduct of coal based power plants, is a combination of complex particles of a variable composition, which are not always homogenous and are mainly dependent on the combustion process, the source of coal and the precipitation technique. Toxic constituents in these particles are considered to be metals, polycyclic aromatic hydrocarbons and silica [Paul,1997,Dwivedi1993). As coal naturally contains heavy metals, some alkaline element etc. Thus fly ash also contains heavy metals (Fulekar 83), Ca, Na, Fe in ionic form and some organic materials, Spheroid Carbonaceous Particles, produced by high temperature coal and oil are also found in significant concentration in surface sediments of lakes and also in stored ash (Shrivastava S.2004), (N.L.Rose,1994),(Rose and Shilling 2004).

These impurities are present in Fly ash polluted water in soluble and non-soluble form and accumulative in inhibiting fauna like fish. These impurities affect their physiological behavior and other responses significantly. Fishes of this type of water bodies are not seemingly healthy in comparison other nearby ponds of same areas. In earlier studies (Peter et al 2009) morphological deformities were seen in fishes living in contaminated rivers. . So this study became necessary to know the affecting factors for fish health, their behavior and physiology in this fly ash polluted water.

Behaviors is a sequence of quantifiable actions (P.N. Dubey 2010) operating through the central and peripheral nervous systems and the cumultative manifestation of genetic, biochemical and physiological process essential to life, such as feeding, reproduction and predator avoidance.Fishes live in a three dimensional environment and their behaviors represents solution to problems encountered in their space.(Stephen et al 2004). 
For the study Tilapia Mozambican were procured because it is considered to be a good bioindicator of toxicity(F M El Et al 99),consumed by nearby population and they were easily available, omnivorous and they don't have any habitat specificity.

To understand the fish behavior in fly ash polluted water we studied Tilapia's response to food (supplied in regular time intervals); Operculum activity, fin movement, rheo-response, acoustic response, etc. Though some earlier studies have been done with tilapia (Jian yu 2005).Limnological studies of fly ash pollution have been studied by Walia 1995 and found many impurities in river Yamuna caused due to fly ash.

\section{Methodology}

For the lab study of behavior, the fishes used were healthy Tilapia. Two aquaria with equal amount of water were taken, keeping constant the water quality, maintained same temperature and aeration. We prepared fly ash bed in one of the aquarium, and the other was kept devoid of fly ash, as control. Fishes of approximately same size and weight were selected (approximately 3-4inches), 3 fishes were kept in each aquarium and same food in equal quantity, at regular time intervals were given. After acclimatization their behavior was observed (Stephan et al 2004) (Malina2006) under the following heads -

I Food response

II Rheo response

III Acoustics response

IV Aggressiveness

$\mathrm{V}$ Operculum activity

VI Fin movement

VII Swim patterns

After acclimatization the fishes were observed for one week continuously for 3 sections ( 2 hour each)

(a) Morning 6-8am)

(b) Noon and (11am-1pm)

(c) Evening. (4-6pm)

\section{Observations}

Refer

Table 1 for food response.

Table 2 for Rheo Response

TABLE 3 for Acoustic Response

TABLE 4 for Aggressiveness

TABLE 5 for Opercular activity

TABLE 6 for Fin Movements

TABLE 7 for swim pattern

\section{Result \& Discussion}

After the observations and study of both the aquarium fishes, The fishes of aquarium with normal water appeared in resting phase and more relaxed, their opercula activity was no significant with less active dorsal, ventral, pelvic \& anal fins in morning time.

The food response was remarkable as the fish in normal water took food at regular intervals and some leftover food was also observed, every time the food was administered. They would detect the food very quickly and would go toward it in a relaxed manner, exept at morning hours observations when they would be seen eagerly gulping the food particles. But the fishes in fly ash polluted water would take a longer time to detect the food but would rush towards it gulping every bit, may it be morning, noon, or evening hours.Joachim et al 2005, have seen the eagerness for food in rainbow trout as a stress management strategies. They confirmed that reactive and proactive stress coping as seen in mammals is also present in rainbow trouts. Thus; this greediness for food can be stated as a stress coping mechanism. 
Fishes are very reactive to rheotaxis. It is very well known that they live and migrate in water on the basis of these responses (William et al1977).In present experiment the fish in polluted environment is showing severe response to slightest rheological disturbance.

The Acoustic response is a direct demonstration of working of lagenar fibre(Z.Lu etal 2003). They have proved that Lagena plays an important role in sound localization specially in underwater acoustic particle movement. In this experiment acoustic response is interestingly faster in fishes in polluted water than of normal water, but this does not mean that there is some problem in perception of sound, but may be they are over reactive and thus tried to swim away quickly from the disturbance, again an example of stress. The direction of sound did not make any difference, at least in the aquarium environment, as also found by Z.Lu,(Z.Lu,A.N.Popper,Fay,96) when they worked on teleost fish and found them equally sensitive to stimulation at all axes in a three dimensional space.The study of opercular movement is best to ascertain the stress. It gives direct relation towards oxygen stress. At morning the opercular movement was not much significant but at noon operculum moved above 145/minute and at evening above 130/minute. They appeared in resting phase (in morning) most of the time food responses was positive but food was not very greedily consumed, other reflexes like acoustics responses fish moved away from the disturbing source but adjusted back very fast, within seconds, like in rheological disturbance when disturbances were created with a glass rod in water, fish reacted aggressively and moved away very fast from the glass rod.

Their operculum activity was non significant with less active dorsal, ventral, pelvic \& anal fins in morning time. At noon \& evening operculum moved above 145/minute and at evening above 130/minute, the movement of pectoral fin was active and moved in waved pattern and moved about 160/min, but dorsal \& caudal fins moved slowly and only posterior portion moved.

Studies of operculum and fin movement were important because they directly related to oxygen consumption and their stress condition. Earlier studies (P.N. Dubeyand Hosseti 2010) have reported frequent gulping of air, which is to avoid toxic medium contact and to ease respiratory stress. But no surfacing and gulping was observed in experiments with fly ash.

Respiratory activity of fish is often the first physiological response to be affected by the contaminants in the aquatic environment. Opercular movement is one of the early warning systems as an indicator of respiratory stress. In case of fly ash exposed fish the opercular movement ranges from 150 -165 per minute, which is far more than the opercular movement in normal water that is 130-150, a clear indication of respiratory stress. Since fishes breath in water in which they live, changes in chemical properties there will surely be reflected in their respiratory activity.Jeane et al 2009, had studied stress in Tilapia with results in same line.

Fish in normal water moved mostly horizontally in aquarium and most of the time settled down in aquarium at an angle of 45 degree to the bottom.

The fish in fly ash water showed very positive food response but they took more time (10 sec. more) to detect the food; the consumption of food was exactly double than fish of aquarium with normal water Fish in fly ash water appeared in resting phase in the morning and their operculum movement were not significant and fin movement were also not significant, only pectoral fin moved very fast above $190 /$ min in waved pattern.

Pectoral fin appeared to move in every section of observation above 190/min. and it's highest at noon. Many fishes use their pectoral fins as their primary propulsions (Malina 2006).In this form of swimming the pectoral fins are actuated synchronously with one another in forward swimming. Alternating fin beats are used in lower speed and synchronous beats in higher speeds. Malina 2006 found these positions distinct as rapid transitions were seen between pectoral fin co-ordinations. This pattern was found to be similar as in many tetra pods as in frogs.

Fishes swim using undulatory movements of their body and their paired and unpaired fin. In this type of movement a backward bending is generated by the sequence of myotomes from head to tail (John et al 1999), Body and caudal fin generating a forward thrust. Different species use their myotome muscle to generate thrust in different ways, in spite of many features being common (John et al 1999).Swimming of these fishes were noted in horizontal and vertical directions, But backward swimming was noted in the fish in fly ash, that too very rarely, but never in fishes of the normal water. Backward swimming has been studied in fishes like eel (Kristian and Peter 1999) where it was found that elongated swimmers can swim backwards in addition to longitudinal undulatory movements.Salma et al 2006, studied the neural coordination underlying swimming and motor pattern where intrinsic function of spinal network is well understood. First of all dog fish was studied for the inter relationship of forward and backward swimming relationship. But no report for such movement in tilapia is reported. Thus we can catch as a hint that there is some mis-coordination developing in the neural network 
responsible for swimming in the fishes of fly ash water, that's why backward swimming is exhibited in fishes of fly ash polluted water.

As for acoustic responses, fish moved away from sound source (tapping with a pencil) quickly but they remained disturbed for a longer period (in fly ash water) and showed streaming movements, some time vertically some time longitudinally in random fashion. These fishes took almost 2 minutes to come back to normal resting conditions, while the fish in normal water adjusted back within 15 seconds.

When we created rheological disturbances by moving a glass rod in water, fish of fly ash water responded aggressively; again moved randomly in almost all direction.

While reacting to this entire disturbance the fishes in fly ash water showed some unique swimming patterns like swimming backwards for 2 inch distance and circular movements.

All these responses showed that the fishes in fly ash water are more stressed, aggressive, hyperactive, over reactive and showed more time to come back to normal condition.

They also seemed to be stressed for $\mathrm{O}_{2}$ as all of them gathered near the Oxygen supply all the time while the fishes in normal water showed no such attraction to the oxygenator.

Another unique pattern difference noticed in their resting condition was that the fishes in normal water settled towards the bottom with an angle of 45 degrees without much hesitation, but fishes with fly ash bed would first sweep away the fly ash with their fins \& water movement, then only they would settle at the bottom.( Steve2004)The angle remained same.

They were so hyper active that even slightest visual, acoustic \& rheological disturbances would startle them and they would start swimming randomly in any pattern.

On external observation the fishes in fly ash seemed to get a red colour touch near their caudal \& dorsal fin edges, the weight gain of fishes in fly ash was nil, though they were always hungry and kept eating whatever was given.

Behaviors allow organisms to adjust to external and internal stimuli in order to best meet the challenges to survive in a changing environment. It is a selective response that is constantly adapting through direct interaction with physical, chemical, social, and physiological aspects of the environment.(P.N. Dubey and Hosseti 2010).

As already studied in many fish that fishes do show bioaccumulation.(Jeng Wei 2006, Min Pie) Attributed to bioaccumulation of heavy metals from fly ash(Dennis,1999)(A. Garcia et al 2008) some changes in nervous system has been recorded, that's why the fishes were showing hyper activity, random swimming and stressed behavior.Gary,2010,has also studied effects of fly ash on the senses of mice by injecting the constituent of fly ash in the mice and attributed all the constituent of fly ash responsible for the irritations in the mice.P.N.Dubey and Hosetti $2010 \mathrm{Had}$ also studied the behavior of fishes in polluted water and observed almost the same results as independency in swimming movements, Hyper excitation, Respiratory dysfunction, which is seen in the present study as the fishes in fly ash water hovered around the oxygenater.Changes in spontaneous locomotor's activity and respiratory responses behaviors are indicators of sub lethal exposures in fishes.

\section{References}

A. Garcia - Sanchez, F. Contreras, M.Adams, F. Santas. (2008). Mercury Contamination of surface water and fish in a gold mining region ( cuyuniriver basin, venezuela). International Journal of Environment and pollution, 2008 - Vol. 33, No. $2 / 3$ pp. 260 -274, 2008. DOI-10.1504/IJEP.2008.019398.

Denis lemly A. (1999). United states forest services, Block burg. Selenium impacts on Fish: An insidious time Borne". Human and Ecological Risk Assessment, Vol. -5, No. 6, PP. 1139-1151.

Dwivedi C.S. and Singh R.M. (1993). The Assessment of Hazard indices of toxic elements from coal Based power plants. Indian J. Enviram Health, 35 (2) : 142-143.

F.M.El-Demerdash; E.I. Elagamy. (1999). Biological effects in Tilapia nilotica fish as indicators of pollution by cadmium and mercury. International Journal of Environmental health research, Vol. 9, Issue-3, September 1999, Pages 173-186 DOI - 10.1080/09603129973146.

Fulekar M.H., Naik D.S. and Dave J.M. (1983). Heavy Metals in Indian coals an corresponding fly ash and their rerlationship with particulate size. Int. J. Environ. Stud, 21 : 179-184.

Gary E.Hatch,Elizabeth Boykin et al. (2010). Effect of Fly Ash and Its Constituents on Sensory irritation in Mice. Vol. 2, Num. 2, pp77-81, 2010. 
Jeane A. Almeida, Rodrigo E. Barreto, Ethel L.B. Novelli, Fabio J. Castro, Sendro E. Moron. (2009). Oxidative stress biomarkers and agressive behaviour in fish exposed to aquatic cadmium concentration. Neotrop. Ic thylerl, Vol 7, No. 1 Porto Alegre Mar. 2009.

Jeng Wei Tsai, Chung-Min Liao. (2006). A Daser based Modelling approchfor accumulation and toxicity of as in Tilapia”. Inc. Environ Toxical, 21:8-21.

Jian-yu Xu, Xiang-wen Miao, Ying Liu and Shao-Rong Cui. (2005). Behavioral responses of Tilapia (Oreochromis niloticus) to acute ammonia stress monitored by computer vision. J. Znejiang Univ. Sci., B. 2005 August; 6(8) : 812-816. DOI - 10.1631/jzus.2005.B 812.

Joachim Schjolden Argavadas Stoskhus Svante Winberg. (2005). Does Individual Variation in stress response andagonistic behaviour reflect divergent stress coping strategies in Juvenile Rainbow trout. Physiological and Biochemical zoology, 78(5) :715-723.

John D. Altringhnam, David J.Ellerby. (1999). Fish swimming patterns in Muscle function. Journal of Experimental Biology, 202, 3397-3403.

Kristiaan D"aout and Peter Aerts. (1999). A kinematic comparison of forwardand backward swimming in theEEL (Anguilla Anguilla). Jornal of Experimental biology, 202,1511-1521.

Malina E Hale,Ryan D.Day,Dean H Thorsen and Mark W Westneat. (2006). Pectoral fin Coordination and gait transitions in steadily swimming juvenile reef fish. Journal of experimental biology, 209, 3708-3718.

Min-Pei Ling, Chung-Min Liao, Jeng-Wei Tsai, and Bo-Ching Chen. (2005). A PBTK/TD Modeling - Based Approach can Assess Arsenic Bioaccumulation in farmed tilapia and human health risk. Integrated environmental assessment and management, 1(1); 40-54.

N.L. Rose and S.Juggins. (1994). Fuel type characterization of spheroidal carbonaceous particles using surface chemistry. Atmospheric Environment, 28:177-183.

P.N. Dubey, B.B. Hosetti. (2010). Behaviour surveillance and oxygen consumption in the fresh water fish labes rohita exposed to sodium cyanide. Biotechnology in Animal husbandary, 26(1-2), p. 91-103.

Paul J.A.Borm. (1997). Aim.accup.Hyg, Vol.41, No.6, pp659-676.

Peter Lin Sun, William E. Hawkins, Robin M. Overstreet, Nancy J. Brown - Peterson. (2009). Morphological deformities as biomarkers in fish from constaminated rivers in taiwan. Int. J. Environ. Res. Public health, 2009, 6, 2307-2331;DOI :10.3390/ijerph 6082307.

Rose N.L., Shilland E., Berg T., Hanselman K., Harriman R., Koing K., Nickus U. Steiner Trad B., Stuchilk E., Thies H. and Ventura M. (2001). Relationship between acid ions and carbonaceious fly ash particles in deposition at European mountain lakes. Water, Air and soil pollution, 130: 1703-1708.

Salma S.Islam, Pavel V. Zelenin, Grigori N Orlovsky, Sten Grillner and Tatiana G Deliagina. (2006). Pattern of motor coordination Underlying Backward swimming in the lamprey. J.Neurophysiology, 96:451-460,2006.

Shrivastava S. 309-312. (2009). Detection of organic Matrials in fly ash by chromatrographic methods. Nature environment and pollution technology, Vol. 8, No. 2.

Stephen J. Walsh, Convener and asmund Bjordal convener. (2004). Fish behaviour in exploted ecosystem; ICES journal of marine scienc: Journal du conseil 200461 (7): 1030-1035 ; DOI :10.1016/j.icesjms.2004.08.006(C).

Steve L. Schleiger. (2004). Fish health assessment index study of four reservoirs in west central georgia, North American journal of Fisheries management, 2004; 24 : 1173-1188. Mean fish health varied significantly over time across reservoirs, sections of reservoirs and species.

Waliya, Archana. (1995). University of Delhi (India) 169 pp. A study on the characteristic leaching and toxicity of fly ash from I.P. Tharomal power station Delhi and the impact assessment of its disposal on the limnology of river Yamuna.

William.C.Leggett. (1977). The Ecology of fish migration. Ann.Rev.Ecol.Syst.

Z.Lu,A.N.Popper,R.R.Fay. (1996). Behavorial detection of acoustic particle motion by a teleost fish, Sensitivityand directionality. Journal of comparative physiology, A:Neuroethology, Sensory, Neural, and Behavorial physiology. Vol 179, No.2 Aug 96, 227-233.

Z.Lu,Z.Xu,W.J.Buscher. (2003). Acoustic response properties of lagner nerve fibres in sleeper Goby Dormitator Latiforns"Journal of Comparitive Physiology A.Neuroethology, sensory, Neural and Behaviour Physiology, Vol. 89, No. 12, Dec 2003. 
Table 1. Food Response

\begin{tabular}{|c|c|c|c|}
\hline $\begin{array}{l}\text { Fishes in normal } \\
\text { water }\end{array}$ & Morning & Noon & Evening \\
\hline Day I & $\begin{array}{c}++ \\
\text { No Food left }\end{array}$ & $\begin{array}{c}+ \\
\text { Food left }\end{array}$ & $\begin{array}{c}+ \\
\text { Food left }\end{array}$ \\
\hline Day II & $\begin{array}{c}++ \\
\text { No food left }\end{array}$ & $\begin{array}{c}+ \\
\text { Food Left }\end{array}$ & $\begin{array}{c}+ \\
\text { Food Left }\end{array}$ \\
\hline Day III & $\begin{array}{c}+++ \\
\text { No Food left }\end{array}$ & $\begin{array}{c}+ \\
+ \\
\text { Food Left }\end{array}$ & $\begin{array}{c}+ \\
+ \\
\text { Food Left }\end{array}$ \\
\hline \multicolumn{4}{|c|}{ Fishes In Fly ash Water } \\
\hline Day I & $\begin{array}{c}+++++ \\
\text { QAFI } \\
\text { No food left }\end{array}$ & $\begin{array}{c}+++++ \\
\text { QAFI } \\
\text { No food left }\end{array}$ & $\begin{array}{c}++++ \\
\text { QAFI } \\
\text { No food left }\end{array}$ \\
\hline Day II & $\begin{array}{c}++++++ \\
\text { QAFI } \\
\text { No food left }\end{array}$ & $\begin{array}{c}+++++ \\
\text { QAFI } \\
\text { No food left }\end{array}$ & $\begin{array}{c}+++++ \\
\text { QAFI } \\
\text { No food left }\end{array}$ \\
\hline Day III & $\begin{array}{c}++++ \\
\text { QAFI } \\
\text { No foodleft }\end{array}$ & $\begin{array}{c}++++ \\
\text { QAFI } \\
\text { No food left }\end{array}$ & $\begin{array}{c}+++++ \\
\text { QAFI } \\
\text { No food left }\end{array}$ \\
\hline
\end{tabular}

QAFI=Quick and aggressive food intake

Table 2. Rheo response \{Fishes moved away from disturbances\}

\begin{tabular}{|c|c|c|c|}
\hline $\begin{array}{c}\text { Fishes in normal } \\
\text { water }\end{array}$ & Morning & Noon & Evening \\
\hline Day I & Quick & Quick & Quick \\
\hline Day II & Quick & Quick & Quick \\
\hline Day III & Quick & Quick \\
\hline Fishes in fly ash & & & \\
\hline water & Quick ++ & Quick +++ & Quick ++ \\
\hline Day I & Quick ++ & Quick +++ & Quick +++ \\
\hline Day II & Quick ++ & Quick +++ & Quick +++ \\
\hline Day III & & & \\
\hline
\end{tabular}

Table 3. Acoustic response

\begin{tabular}{|c|c|c|c|}
\hline $\begin{array}{c}\text { Fishes in normal } \\
\text { water }\end{array}$ & Morning & Noon & Evening \\
\hline Day I & $4 \mathrm{Sec}$. & $3 \mathrm{Sec}$. & $3 \mathrm{Sec}$. \\
\hline Day II & $4 \mathrm{Sec}$. & $3 \mathrm{Sec}$. & $2 \mathrm{Sec}$. \\
\hline Day III & $2 \mathrm{Sec}$. & $4 \mathrm{Sec}$. & \\
\hline $\begin{array}{c}\text { Fishes in flyash } \\
\text { water }\end{array}$ & & & \\
\hline Day I & $1 \mathrm{Sec}$. & $1 \mathrm{Sec}$. & $1 \mathrm{Sec}$. \\
\hline Day II & $1 \mathrm{Sec}$. & $1 \mathrm{Sec}$. & $1 \mathrm{Sec}$. \\
\hline Day III & $1 \mathrm{Sec}$. & $1 \mathrm{Sec}$. & \\
\hline
\end{tabular}


Table 4. Aggressiveness \{in totality of responses\}

\begin{tabular}{|c|c|c|c|}
\hline $\begin{array}{c}\text { Fishes in normal } \\
\text { water }\end{array}$ & Morning & Noon & Evening \\
\hline Day I & NA & R S & NA \\
\hline Day II & R S & NA & NA \\
\hline Day III & NA & NA & NA \\
\hline $\begin{array}{c}\text { Fishes in fly ash } \\
\text { water }\end{array}$ & & & RA \\
\hline Day I & RA & RA & RA \\
\hline Day II & RA & RA & RA \\
\hline Day III & RA & RA & \\
\hline
\end{tabular}

$\mathrm{RA}=$ Responds Aggressively

$\mathrm{NA}=$ Non Aggressive

Table 5. Operculum activity \{Per Minute $\}$

\begin{tabular}{|c|c|c|c|}
\hline $\begin{array}{c}\text { Fishes in normal } \\
\text { water }\end{array}$ & Morning & Noon & Evening \\
\hline Day I & Not significant & 140 & 132 \\
\hline Day II & Not significant & 150 & 130 \\
\hline Day III & Not significant & 145 & 135 \\
\hline
\end{tabular}

\begin{tabular}{|c|c|c|c|}
\hline $\begin{array}{c}\text { Fishes inFly ash } \\
\text { water }\end{array}$ & & & \\
\hline Day I & Not significant & 160 & 150 \\
\hline Day II & Not significant & 165 & 152 \\
\hline Day III & Not significant & 162 & 155 \\
\hline
\end{tabular}

Table 6. Fin movement \{per minute\}

a. Pectoral fin

\begin{tabular}{|c|c|c|c|}
\hline $\begin{array}{l}\text { Fishes in normal } \\
\text { water }\end{array}$ & \multicolumn{1}{|l|}{ Morning } & Noon \\
\hline Day I & 165 & 160 & 168 \\
\hline Day II & 167 & 164 & 170 \\
\hline Day III & 160 & 170 & 168 \\
\hline
\end{tabular}

\begin{tabular}{|c|c|c|c|}
\hline $\begin{array}{c}\text { Fishes in fly ash } \\
\text { water }\end{array}$ & 2 & \\
\hline Day I & 205 & 240 & 230 \\
\hline Day II & 190 & 210 & 205 \\
\hline Day III & 200 & 205 & 203 \\
\hline
\end{tabular}




\section{b. Caudal fin}

Only upper posterior portion moved \{in per minute\}

\begin{tabular}{|c|c|c|c|}
\hline $\begin{array}{c}\text { Fishes in normal } \\
\text { water }\end{array}$ & Morning & Noon & Evening \\
\hline Day I & 35 & 30 & 32 \\
\hline Day II & 30 & 28 & 30 \\
\hline Day III & 34 & 30 & 32 \\
\hline $\begin{array}{c}\text { Fishes in fly ash } \\
\text { water }\end{array}$ & & & \\
\hline Day I & NS & NS & NS \\
\hline Day II & NS & NS & NS \\
\hline Day III & NS & NS & \\
\hline
\end{tabular}

\section{c. Dorsal fin}

\begin{tabular}{|c|c|c|c|}
\hline $\begin{array}{c}\text { Fishes in Normal } \\
\text { water }\end{array}$ & Morning & Noon & Evening \\
\hline Day I & NS & NS MSP & NS MSP \\
\hline Day II & NS & NS & NS MSP \\
\hline Day III & NS & NS & NS \\
\hline $\begin{array}{c}\text { Fishes in fly ash } \\
\text { water }\end{array}$ & MSP & NS & MSP \\
\hline Day I & NS & NS & NS \\
\hline Day II & NS & & \\
\hline Day III & & & \\
\hline
\end{tabular}

MSP-Mostly in standing position

NS-Non significant

Table 7. Swim pattern \{per minute\}

\begin{tabular}{|c|c|c|c|}
\hline $\begin{array}{c}\text { Fishes in normal } \\
\text { water }\end{array}$ & Morning & Noon & Evening \\
\hline Day I & $\mathrm{H}-6 / \mathrm{min}$ & $4 / \mathrm{min}$ & $4 / \mathrm{min}$ \\
& $\mathrm{V}-1$ & $6 / \mathrm{min}$ & 1 \\
\hline Day II & $\mathrm{H}-5 / \mathrm{min}$ & 1 & $5 / \mathrm{min}$ \\
& $\mathrm{V}-2$ & $5 / \mathrm{min}$ & 1 \\
\hline Day III & $\mathrm{H}-6 / \mathrm{min}$ & $1 / \mathrm{min}$ & $1 / \mathrm{min}$ \\
& $\mathrm{V}-1 / \mathrm{min}$ & $\mathrm{H}-10$ & $\mathrm{H}-14$ \\
Fishes In fly ash & $\mathrm{H}-12$ & $\mathrm{~V}-3$ & $\mathrm{~V}-4$ \\
water & $\mathrm{V}-4$ & $\mathrm{~B}-2$ & $\mathrm{H}-10$ \\
Day I & & $\mathrm{H}-12$ & $\mathrm{~V}-4$ \\
\hline Day II & $\mathrm{H}-10$ & $\mathrm{~V}-2$ & $\mathrm{H}-12$ \\
& $\mathrm{~V}-5$ & $\mathrm{H}-12$ & $\mathrm{~V}-4$ \\
\hline Day III & $\mathrm{H}-13$ & $\mathrm{~V}-5$ & \\
\hline
\end{tabular}

$\mathrm{H}=$ Horizontal, $\mathrm{V}=$ vertical

$\mathrm{H}=$ Horizontal, $\mathrm{V}=$ vertical

$\mathrm{B}=$ Backwards 